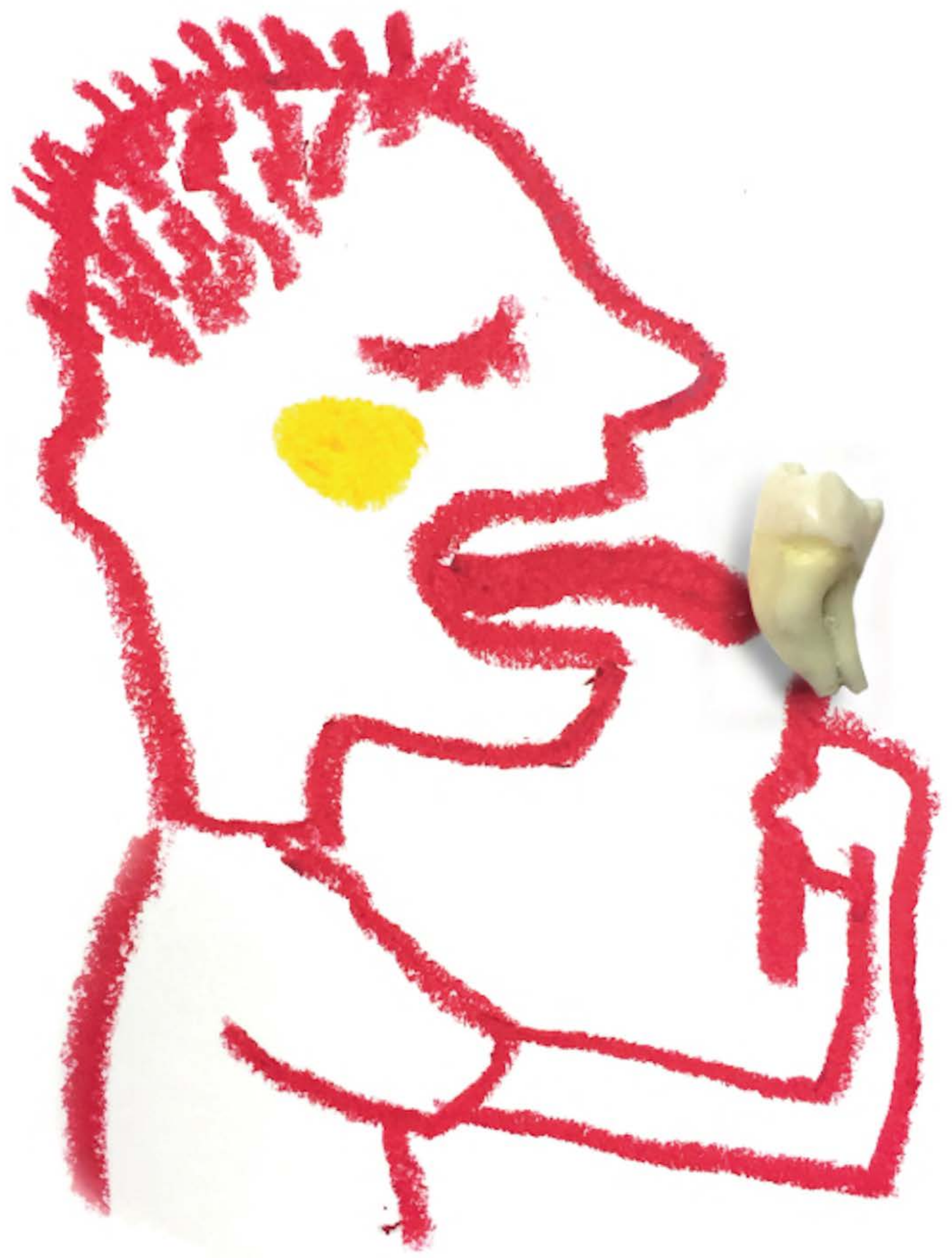


Creative

Economy

at Girona, Spain:

a potential,

a hope, and

investments

to be

Guilherme-Fráguas Nobre 


\section{Creative Economy at Girona, Spain: a potential, a hope, and investments to be}

\section{Guilherme-Fráguas Nobre}

fraguasnobre@gmail.com | Investigador asociado, Instituto de Tecnología de la Comunicación de la Ciencia; investigación postdoctoral en Ciencias de la Comunicación, equipo GRESEC, Cristal/Université Stendhal, Grenoble, Francia.

Fecha de recepción: 10 febrero 2017

Fecha de aceptación: 23 mayo 2017

\section{Resumen}

Algunos actores clave consideran la "economía creativa" (o la "economía del conocimiento", "industrias creativas", etc.) como una alternativa viable para que Girona escape del modelo socioeconómico tradicional, basado en la agricultura, la industria pesada y los servicios de baja tecnología. Aunque la retórica de los jefes locales y regionales del gobierno parece adherirse a tal opinión, los datos revelan una fuerte concentración de tales actividades en la Provincia de Barcelona. En realidad, un estudio sobre los datos disponibles para Girona muestra su economía profundamente arraigada en los servicios, en su mayoría intensivos en competencias gerenciales. Por lo tanto, se sugiere que Girona también se enfoque en la 'economía creativa' desde una perspectiva gerencial, abarcando el concepto más amplio de 'economía de la experiencia', en el sentido dado por los países escandinavos.

Palabras clave | economía creativa; Girona; sectores creativos; industrias creativas. 
CREATIVE ECONOMY AT GIRONA, SPAIN:

A POTENTIAL, A HOPE, AND INVESTMENTS TO BE

\begin{abstract}
Some key players have been considering the 'creative economy' (or the 'knowledge economy', 'creative industries', etc.) as viable driver for Girona to escape from the traditional socioeconomic model based on agriculture, hard industry, and low-tech services. Although the rhetoric from the local and regional heads of the government seems to adhere to such an opinion, the facts reveal a strong concentration of such activities in the Province of Barcelona instead. Actually, a study over the data available of Girona shows its economy deep-seated at services mostly intensive on managerial competences. Therefore, it is suggested that Girona also approaches the 'creative economy' from a managerial perspective, embracing the wider concept of 'experience economy' - in the sense given by the Scandinavian countries.
\end{abstract}

Keywords | creative economy; Girona; creative sectors; creative industries. 
CREATIVE ECONOMY AT GIRONA, SPAIN:

A POTENTIAL, A HOPE, AND INVESTMENTS TO BE

\section{Introduction}

Girona has creative sectors and industries as any other provincial capital with artists, museums, historical sites, theatres, architects, designers, sports events, fairs, touristic attractions, restaurants amid the best in the world (e.g. El Celler de Can Roca and El Bulli), an university ambience, a technology park, and much more that is usually included as component of the creative economy ${ }^{1}$ (see Unesco, 2013, 22). However, the lack of

studies, researches and data about Girona's own creative economy is a matter that the recent local government has been trying to fix. Therefore, there is a gap between what a person can infer Girona has (as creative economy) and in what a person can base itself in order to justify such position - because, again, data are scarce ${ }^{2}$. Nonetheless such relative absence of measurements and analysis, the last two City Hall administrations have been investing into the creative economy as a viable development driver for Girona. This paper faces then an apparent paradox: to reunite the available material covering the creative economy at Girona, while dealing with the fact that what is available is much more a set of perceptions, policies to be implemented, political speeches, and social hope. Thus, this paper aligns itself with the efforts of those who seek to better understand and study the creative economy of Girona, which already exists as a phenomenon, but whose analysis and research is only in its beginning. As a contribution to the debate, the paper suggests that Girona should invest both directly into the creative sectors and industries, as well as indirectly via its managerial potential which can be eventually applied to support the creative sectors and industries whether at the local level or attracted from Barcelona.

\footnotetext{
1 "Actualment, I'economia creativa i cultural es presenta com un concepte holístic que integra les interaccions que hi ha entre cultura, economia i tecnologia, tot estimulant la inclusió social, la diversitat cultural i el desenvolupament humà. (...) Es tracta d'un grup heterogeni d'activitats basades en el coneixement que difonen bens tangibles i serveis intel-lectuals i/o artístics amb un alt contingut creatiu, però també amb valor econòmic i de mercat." (Ajuntament de Girona, 2015a, p. 2-3) "Actually the cultural and creative economy is a holistic concept that integrates the existing interactions between culture, economy, and technology, while promoting social inclusion, cultural diversity, and human development. (...) It is a heterogeneous group of knowledge-based activities that spread both tangible goods and intellectual/artistic services with a high creative content, but also with economic and market value". (free translation)

2 "Es difícil hacer cálculos sobre cómo y en qué medida la economía (de Girona) va transformándose hacia una economía creativa (ya que) disponemos de pocos indicadores estadísticos que estén adaptados a los conceptos como creatividad, industria cultural, innovació (...). Los indicios sobre su transformación hacia una economía creativa podrían considerarse más cualitativos que cuantitativos (...)". (Ajuntament de Girona, personal communication, March 23 th, 2017) "It is hard to make calculations on how and in which extent Girona's economy evolves towards the creative economy since we have few statistical indicators adapted to concepts such as creativity, cultural industry, innovation (...). The indicia about its transformation into a creative economy may be considered more qualitative than quantitative (...)" [free translation]
} 


\section{Creative economy dimension ${ }^{3}$}

The creative economy represents $6,1 \%$ of the world's Gross Domestic Product (2.700 billion of dollars), while the exports of creative goods and services reached 3,4 \% of the total worldwide (424 billion of dollars) (Area Metropolitana de Barcelona, 2011, 71). In Europe, both the creative and cultural industries generated 3,3\% of the GDP, and have employed $3 \%$ of the working force $(6,7$ million of persons) (Azqueta, 2014, 1). Differently, EY (2014, 10) says that "creative and cultural industries (CCI) contributed with $4,2 \%$ of Europe's GDP". In Spain, the creative and cultural sectors provide with 3,9\% of the country's GDP - average between 2000-2008 (Barcelona Treball, 2013, 17). The region of Catalonia has been close to such mark, with 3,1\% of GDP, 6,6 \% of the working force, and $6.6 \%$ of the companies as well (Generalitat de Catalunya, 2014, 58-59). If one takes the industries based on experiences (that aggregate creative and cultural industries, tourism, and sports), they account for $16 \%$ of the GDP and $19 \%$ of the employments (Generalitat de Catalunya, 2013, 17). The capital Barcelona concentrates $46,8 \%$ of all creative jobs in Catalonia, and has a creative sector that employs $11,3 \%$ of the city's working force and involves 10,9 $\%$ of the companies. (Ajuntament de Barcelona, 2015, 10).

Girona refers to the province and capital city of a province. Although some authors have tried to consider Girona as a part of a macro-region, as a component of a Pyrenees' "technological triangle" that includes Spain and France (Ulrich, 2012), or as an axe of the hyperterritory GI-BAR-TAR (Girona, Barcelona, Tarragona) (Gausa, 2010, 64-65), the truth is that there is an economic concentration on Barcelona since "the province (of Barcelona) contains $86.5 \%$ of the region's culture and creative industries workers" (OECD, 2010, 100). Girona holds about 6,2\% of the Catalonia's employment in culture and creative industries followed by Tarragona with 4,6 \% and Lleida with 2,8 \% (101). Nonetheless, Girona is considered the second cultural city of Catalonia where the creative industries are supposed to become "el motor dinamitzador de l'activitat cultural de la ciutat, (...) i una contribució a l'activació de l'economia creant ocupació"4 (Bòlit Emprèn, 2013, 3).

3 Sometimes data do not reflect the US crisis of 2008, whose impacts in Spain only recently have lessen. 
CREATIVE ECONOMY AT GIRONA, SPAIN:

A POTENTIAL, A HOPE, AND INVESTMENTS TO BE

\section{Girona's economy}

The City of Girona's economy is primarily based on services (49,96\%), commerce $(38,57$ $\%)$, and equipment $(6,52 \%)$ - three sectors that altogether represented $95,05 \%$ of the activity types for the year 2015. Here were taken the number of the elements in each activity (Ajuntament de Girona, 2016). Inside equipment, the most representative categories are public administration (18,01\%), religious equipment (16,62 \%), technical services $(6,65$ $\%)$, Bressol schools $(6,65 \%)$, sanitary equipment $(5,82 \%)$, university centers $(5,26 \%)$, sports complexes and other equipment (4,90\%), civic and social centers (4,44\%), and other educational equipment $(3,32)$ - which represent $71,67 \%$ of the total for equipment. The most relevant categories for commerce are other types of retail $(25,48 \%)$, food and beverage $(18,03 \%)$, bars $(16,96 \%)$, restaurants $(9,37 \%)$, home articles $(4,22 \%)$ - with $74,06 \%$ of the total for commerce. Finally, the main elements of the services are: other services $(41,18 \%)$, personal and corporate services (14,35\%), sanitary services (12,58 \%), lodging (7,99\%), construction and living (7,95 \%), fiscal and economic services (7,19\%) totalizing $91,24 \%$ for services.

\begin{tabular}{|c|c|c|c|}
\hline Macromagnituds i impostos & Girona & Gironès & Catalunya \\
\hline \multicolumn{4}{|l|}{ Producte interior brut (base 2010). 2014} \\
\hline PIB (milions d'euros) & 3.277 .4 & $5.092,7$ & $206.776,3$ \\
\hline PIB per habitant (milers d'euros) & 34,4 & 28,1 & 27,8 \\
\hline PIB per habitant (index Catalunya $=100$ ) & 123,6 & 101,1 & 100,0 \\
\hline \multicolumn{4}{|c|}{ Valor afegit brut (base 2010). Per sectors. Milions d'euros. 2014} \\
\hline Agricultura & 0,7 & 49,9 & $1.947,7$ \\
\hline Indústria & 335,9 & 786,1 & $37.533,7$ \\
\hline Construcció & 126,7 & 243,9 & $8.882,4$ \\
\hline Serveis & $2.558,3$ & $3.615,4$ & $142.273,3$ \\
\hline Total & $3.021,6$ & $4.695,2$ & $190.637,2$ \\
\hline \multicolumn{4}{|c|}{ Valor afegit brut (base 2010). Indústria. Per branques. Milions d'euros. 2014} \\
\hline Indústries extractives, energia, aigua i residus & 51,9 & 89,1 & $5.611,0$ \\
\hline Alimentació, tèxtil, fusta, arts gràfiques, química i cautxú & 220,0 & 510,7 & $18.947,2$ \\
\hline Metal-lúrgia, maquinària, material elèctric i de transport & 64,0 & 186,3 & $12.975,5$ \\
\hline Total & 335,9 & 786,1 & $37.533,7$ \\
\hline \multicolumn{4}{|c|}{ Valor afegit brut (base 2010). Serveis. Per branques. Milions d'euros. 2014} \\
\hline Comerç & 409,4 & 756,6 & $30.649,8$ \\
\hline Transport, informació i comunicacions & 212,2 & 275,0 & $17.458,5$ \\
\hline Hostaleria & 144,2 & 214,9 & $11.034,9$ \\
\hline Act. financeres $i$ assegurances & 175,4 & 214,4 & $7.670,9$ \\
\hline Act. immobiliàries, tècniques $i$ administratives & 616,7 & 919,7 & $40.401,9$ \\
\hline Administració pública i altres serveis & $1.000,4$ & $1.234,8$ & $35.057,3$ \\
\hline Total & $2.558,3$ & $3.615,4$ & $142.273,3$ \\
\hline
\end{tabular}

4 "the dynamical engine for the city cultural activity, (...) and a contribution to activate the economy while creating jobs". [free translation]. 
CREATIVE ECONOMY AT GIRONA, SPAIN:

A POTENTIAL, A HOPE, AND INVESTMENTS TO BE

When measured by the Gross Domestic Product (GDP) in dollars, the sector of services represent 78,06 \% of Girona's economy, followed by the sector of industry with 10,25 $\%$ of the total. The main components of services are public administration and other services $(30,52 \%)$, realtor/technical/administrative activities (18,82\%), commerce $(12,49 \%)$, transport/l\&C (6,47\%), finance/insurance (5,35\%), and hotels $(4,40 \%)$ - making 78,05 $\%$ of the total. The internal distribution for industry is food/textile/wood/chemical/graphic/ cork (6,71\%), extractive/energy/water/waste industries (1,58\%), and metal/machinery/ electric/transport material (1,95\%). However, there is a way to deepen the analysis of the Girona's economy, showing a more complete internal partition for each sector.
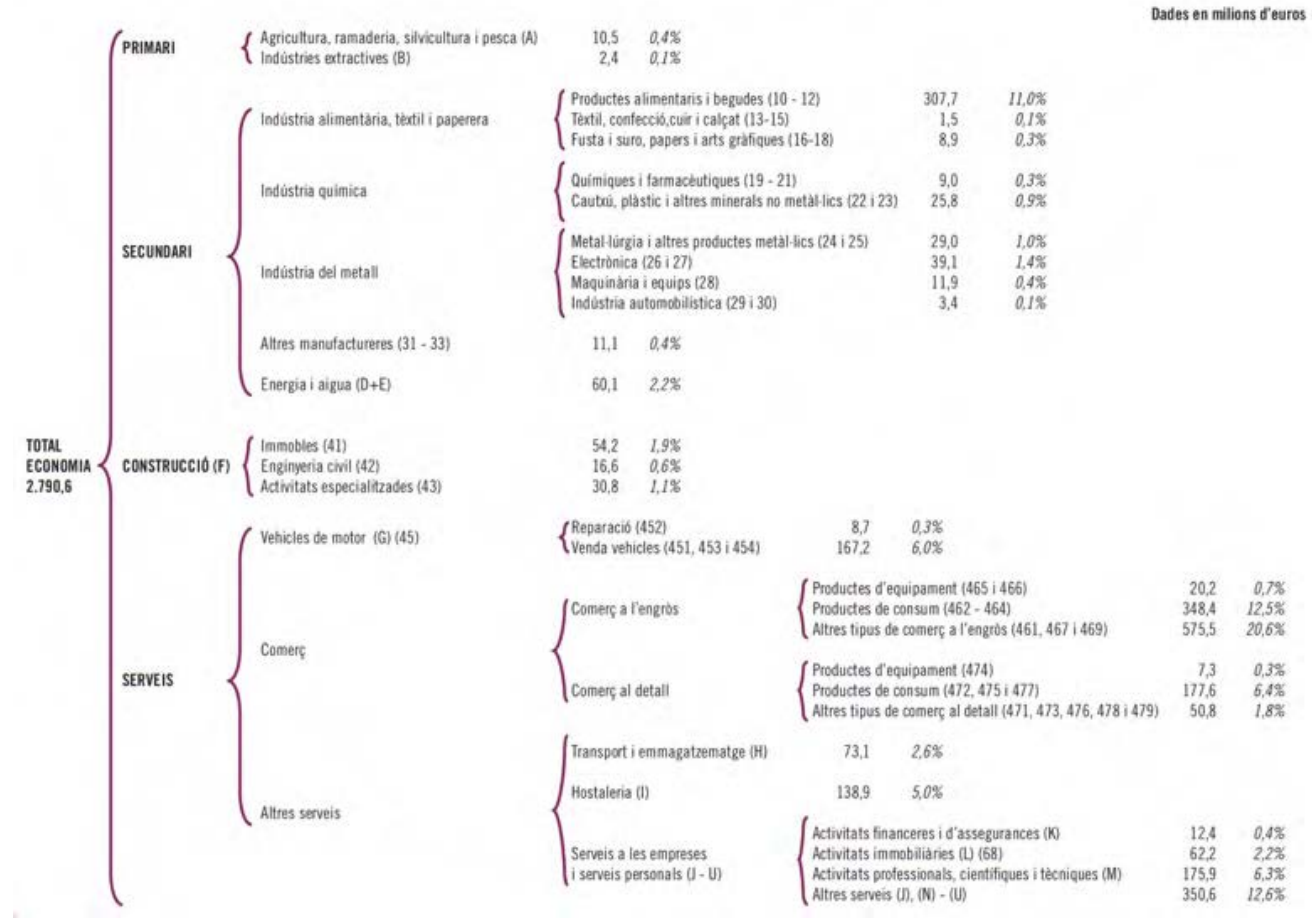

Figura 2. (Perfil de la Ciutat,
2016, 157)

From there, it is clear that the Girona's economy is widely based on services $(78,6 \%)$ and industry $(14,5 \%)$ with the major participation from other types of wholesale commerce $(22,4$ $\%)$, retail/wholesale consumption products $(19,2 \%)$, other services $(11,8 \%)$, food/beverages $(10,5 \%)$, and professional/scientific/technical activities $(6,1 \%)$ - that sum up together $70 \%$. One may note a difference between the numbers presented by IDESCAT and Perfil de 
la Ciutat: at IDESCAT the GDP is $\$ 3.277 .400$ euros, whereas the value depicted at Perfil de la Ciutat is $\$ 2.790 .677$ euros. Going beyond that, a generic category labeled as "other types of" does really few to shed light over the economy's structure. For example, at the Ajuntament de Girona's appraisal, other "types of retail" accounted by 25,48 \% of the category commerce, while "other services" represented $41,18 \%$ of the category services ${ }^{5}$. At the IDESCAT analysis, the "public administration and other services" responded for 30,52 \% of the services sector; whereas at the Perfil de la Ciutat "other types of wholesale commerce" and "other services" expressed $22,4 \%$ and $11,8 \%$ of the sector services - respectively. A manner to contour such generality may be given by the KPMG annual report Girona100.

5. Altres Serveis i Construcció
Clínica Girona, SA
Construcciones Rubau, SA
Eurofirms ETT, SL
Marlex Gestió ETT, SLU
Pannini España, SA
Transportes Calsina y Carré, SL

5. Altres Serveis i Construcció

Clínica Girona, SA

Construcciones Rubau, SA

Marlex Gestió ETT, SLU

Transportes Calsina y Carré, SL

\section{Altres comerços}

Agri-Energia, SL

Cavip, SA

Dyneff España, SLU

Hamelin Brands, SL

Media Markt Girona video-TV-HiFi-Elektro-Computer-Foto, SA

Saima Productos y Servicios, SL

Vera Continental, SL

Vicens i Batllori, SL

Xarxa Farmacèutica, SL

Although the objective of a KPMG's analysis is to consider only the first 100 companies by volume of revenues, it can give a clue over the "other types of" internal composition. For instance, at its Figure 3 are introduced the amounts of business (\%) performed either by familiar or non-familiar companies (KPMG, 2016, 26). The familiar units are concentrated on meat industry (34,15\%), food/beverage/tobacco distribution (21, $49 \%)$, and other manufactory industry $(16,09 \%)$; whereas the non-familiar are rooted on the other commerce $(35,14 \%)$, non-meat food industry $(24,06 \%)$, and other manufactory industry $(22,62 \%)$. At its Annex 2 the KPMG report names the companies individually $(2006,71-72)$. Given

5 The City Hall was contacted to disaggregate the constituents of the $41,18 \%$ other services, but it did not. 
that Girona's economy is highly concentrated on services and commerce, now it is possible to figure out who actually composes the "other type of" category. At "other services" it brings: one health clinic, one human capital firm, and two transport/logistic companies. At the "other commerce" it portrays, one chain of pharmacies, one energy group, one bulk cereal and flour dealer, one fuel distributor, one paper/cardboard industry, one trader for cosmetic / dietetic / odontology / parapharmacy products, one consumer-goods hypermarket, and two suppliers of products for agriculture / livestock.

\section{Creative economy at Girona}

In "El Decàleg de Girona 2010" the seventh commitment was made over the city's image branding, which planned to invest in the intangible asset "Giron@: societat creativa" (Cambra de Comerç de Girona, 2010, 15). It is worthy to note the suggested link between creativity and internet (or technology) given by the symbol @. The main ideas stated into the Decàleg were the exhaustion of the current economic development model; the need for a qualitative shift and a new model; a qualitative shift based on trust, innovation, connectivity, knowledge, networking, cooperation, and cultural change. For it, the creativity "esdevé un factor de competitivitat de primer nivell"6 (182). However, the Decàleg was referring to the knowledge economy and bringing no mention to the expression 'creative economy'?

Under Mayor Carles Puigdement (2011-2015), the Plan for the Government of the Girona

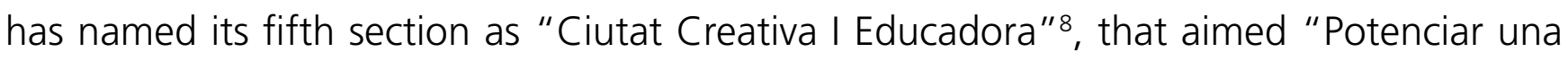
ciutat creative I educadora" 9 . The referred section proposed 39 objectives, amongst which "Potenciar els creadors gironins" 10 and the "Pla d'excellència en I'ús de les TIC"11 (Ajuntament de Girona, 2011, 16). Girona has also been classified as a 'creative city' by Panal and

\footnotetext{
6 "becomes a first level competitive factor" [free translation].

7 "Girona: creative society" [free translation].

8 "creative and educational city" [free translation].

9 "to potentiate a creative and educational city" [free translation]

10 "to potentiate the Girona's creatives" [free translation]

11 "plan of excellency on the ICT's use" [free translation].
} 
Yáñez $(2012,102)$, a typology applied for them to another 45 cities in Spain. The other two typologies were 'artistic cities' and 'entertaining cities'. In their words, creative cities are the ones that stand out due to the "importancia del sector audiovisual y del entretenimiento, sobre todo, en las fases de creación, producción y fabricación. Se trataría de los típicos cluster industriales centradas en estos sectores y actividades" 12 (91). According to Ganau, Paül, and Rierapp (410), in Girona 7,2 \% of the companies belong to the creative economy, even though only $4,7 \%$ of the workers have been labeled creative. To those authors, Girona is the third more important hub for creative economy in Catalonia and it follows just after Barcelona city and Barcelona metropolitan region.

\begin{tabular}{|lrrrrr|} 
& Población & Empresas & Trabajadores & $\begin{array}{l}\text { Empresas } \\
\text { Creativas }\end{array}$ & $\begin{array}{l}\text { Trabajad. } \\
\text { Creativos }\end{array}$ \\
\hline Barcelona ciudad & 21,7 & 30,6 & 33,1 & 47,7 & 53,5 \\
\hline Resto Reg. Met. Barcelona & 44,9 & 35,6 & 36,9 & 29,1 & 30,7 \\
\hline Camp de Tarragona & 8,2 & 7,7 & 7,3 & 5,5 & 4,5 \\
\hline Girona & 9,8 & 10,5 & 9,0 & 7,2 & 4,7 \\
\hline Catalunya Central & 6,9 & 6,3 & 5,7 & 4,5 & 3,2 \\
\hline Lleida & 4,8 & 5,6 & 5,1 & 4,1 & 2,6 \\
\hline Terres de l'Ebre & 2,6 & 2,4 & 2,0 & 1,4 & 0,7 \\
\hline Alt Pirineu i Aran & 1,0 & 1,3 & 0,9 & 0,6 & 0,2 \\
\hline Catalunya & 100,0 & 100,0 & 100,0 & 100,0 & 100,0 \\
\hline
\end{tabular}

Figura 4. Distribución de empresas creativas por vegueries. Ganau, Paül, and Rierapp $(2012,410)$

As stated in Méndez et al. $(2012,24)$, Girona comes in the $26^{\text {th }}$ position on the ranking for the "Especialización en economía creative de las principales áreas urbanas, 2009"13. Conforming to the Perfil de la Ciutat $(2016,116)$, Girona is the municipality that concentrates the highest percentage (60\%) of workers in the sectors of technology and in the sectors based on knowledge, and this way ahead from the average in Catalunya (41,4\%). In line with the IERMB, beyond Barcelona only three 'cities' present an equilibrium to Catalu-

\footnotetext{
12 "importance of the audiovisual and entertainment sectors, especially in the phases of creation, production, and manufacturing. These would be the typical industrial clusters centered on those sectors and activities" [free translation].

13 "Main urban areas' specialization in creative economy" [free translation].
} 
CREATIVE ECONOMY AT GIRONA, SPAIN:

A POTENTIAL, A HOPE, AND INVESTMENTS TO BE

nya: Girona-Costa Brava, Reus-Tarragona, and Lleida. Those metropolises are here named "knowledge platforms", since they can organize "les pròpies ciutats i els territoris propers, beneficiant-se tant de les externalitats subministrades per aquests territoris dels voltants -el paisatge, la qualitat del medi ambient, les infraestructures- com de la proximitat al nucli de Barcelona"14 (2012, 294).

A Girona, les indústries creatives (...) (p)er tipus d'activitat, tenen un major pes els Serveis d'Arquitectura i enginyeria (19,2\%), les de Recerca i desenvolupament $(17,6 \%)^{15}$, les de Serveis de tecnologies de la informació $(14,4 \%)$ i les Activitats professionals i tècniques (disseny, fotografia). (Ajuntament de Girona, 2015a, 8) "At Girona the creative industries by type are concentrated in Architecture and Engineer services (19,2\%), Research and development (17,6\%), Information technologies services $(14,4 \%)$, and Professional and technical activities (design, photography)" [free translation].

More recently, Girona Emprèn has proposed that "(I)a cultura i la creativitat són motors econòmics del territorio gironí"16 (2014). Also, the current City Hall has just presented a project where the cultural and creative industries are taken as "a motor econòmic de futur"17. The Mayor Mrs. Marta Madrenas said that the project will incorporate both the traditional and the new cultures, such as multimedia, videogames, and series. One of the actions previewed is the launching of the mark "Girona Crea"18. (Adjuntament de Girona, 2016a). This year the Provincial Government of Girona has applied for European Regional

\footnotetext{
14 "their own cities and territories, benefiting from both the externalities provided by such territories (landscape, environment quality, infrastructures) and the proximity to Barcelona". (free translation).

15 "En el cas de l'afiliació al Règim General (...) les activitats creatives han augmentat els seus efectius en un 4,2 \% mentre el total d'afiliats s'ha reduït un 3,5 \%. (P)erò, la xifra és enganyosa donat que una part importantíssima de l'increment dels afiliats es produeix per l'augment de l'afiliació sota l'epígraf de Recerca i desenvolupament. Augment forçat per l'obligació, a partir de 2011, de regular la situació laboral i incloure en el RGSS les persones que participen en programes de formació vinculats a estudis universitaris o de FP (becaris)." (Ajuntament de Girona, 2015a, p. 9) "Regarding the affiliation to the General Regime (...) the creative activities have increased its workforce by $4.2 \%$, while the total number of affiliations have decreased by $3.5 \%$. (B) ut such data is misleading because a significant part of the increase in affiliations is due by the increase into the research and development category. Such increase was forced by the obligation, since 2011, to regulate the working situation (and to include it at the RGSS) of people participating in training programs linked to universities or in FP (scholarship holders)." (free translation).

16 "the culture and the creativity are the economic engines for the territory of Girona" (free translation).

17 "an economic engine for the future" [free translation].

18 "Girona creates" [free translation].
} 
CREATIVE ECONOMY AT GIRONA, SPAIN:

A POTENTIAL, A HOPE, AND INVESTMENTS TO BE

Development investment lines through 5 PECT, which stands for Specialization and Territorial Competitiveness Projects. One of them aims the cultural and creative sector, as follows:

Els àmbits, imports i objectius dels 5 PECT són els següents: (...) Indústries culturals i creatives de Girona i el seu entorn territorial. (...) Desenvolupament d'un projecte estratègic del sector de les indústries culturals i creatives amb I'objectiu que sigui un motor dinamitzador de l'activitat cultural del territori, una eina de coordinació i foment de les arts, que contribueixi a l'activació de l'economia i generi ocupació de qualitat. El projecte comporta: -Establir vincles entre disciplines i camps de treball, entre les empreses i centres de $\mathrm{R}+\mathrm{D}+\mathrm{i}$, i crear xarxes de treball colølaboratiu. -Proporcionar espais i eines innovadores per facilitar la innovació i la competitivitat, i serveis especialitzats en les ICC. -Visibilitzar el sector, augmentar el públic consumidor de productes culturals, impulsar noves experiències de consum cultural, fomentar l'exhibició i estimular la demanda cultural. -Promocionar l'esperit emprenedor, situar el coneixement i la innovació com a eix prioritari per a la projecció del territori. -Establir vincles amb noves formes de mecenatge i patrocini, oferir sortides i crear oportunitats de treball en relació amb els estudis en arts de la ciutat de Girona i comarques ${ }^{19}$. (Diputació de Girona, 2016)

One of the candidates who ran for Mayor in 2011, Pia Bosch, had the intent to transform Girona into Catalunya's Silicon Valley. At that time, Mrs. Bosch believed that "la ciutat té suficients atractius per convertir-se en un iman per al talent i sortir de la crisi recolzant-se en la innovació"20 (Diari de Girona, 2011) In fact there are other examples that compare

\footnotetext{
19 "The scope, issues, and objectives of the 5 PECT are the following: (...) Cultural and creative industries of Girona and its surrounding territory. (...) Development of a strategic project for the sector of cultural and creative industries with the aim that it remains as a dynamical engine of the cultural activity in the territory, a tool of coordination and promotion of the arts, contributing to the activation of the economy and creating jobs with quality. The project entails: To establish links between disciplines and fields of work between companies and R\&D centers, and to create networks of collaborative work. -To provide spaces and innovative tools to facilitate innovation and competitiveness, and specialized services in the CCl. -To make the sector visible, increasing the public that consumes cultural products, to promote new experiences of cultural consumption, enhancing exhibitions and stimulating the cultural demand. -To promote entrepreneurship, placing knowledge and innovation as a priority for the projection of the territory. -To establish links with new forms of patronage and sponsorship, offering tours and creating job opportunities related to arts studies about the city of Girona and counties" [free translation]

20 "the city has enough attractiveness to convert itself into a magnet for talent and to recover from its crises thanks to innovation" [free translation]
} 
Girona with the Silicon Valley, such as: Mr. Salvador Sunyer wanted to convert Girona into de Silicon Valley of the Arts (Diari de Girona, 2013); Mr. Artur Mas, the former Provincial Governor, considered Catalunya as the world's food industry Silicon Valley (Agencia INCAT, 2014); and Mr. Carles Puigdement, now as Catalonia's Governor, has seen potential for Catalunya both to compete and cooperate with the USA Silicon Valley (Aldia, 2016).

Girona has also tried some practical initiatives to exert the creative economy such as creative tourism (Ajuntament de Girona, 2014; Creative Tourism Girona, 2016); sports training hub for cycling (The Guardian, 2015) and also other sports such as running and tennis (Ajuntament de Girona, 2015); a supportive platform, training kits for creative professionals, and networking rounds to connect companies and local artists (Bòlit Emprèn, 2013); an international mapping festival, whose ambition is to "(s)trengthen Girona's position as a creative city and encourage the transfer of knowledge between the technology and cultural sectors" (Ajuntament de Girona, 2014a, 3); an specialized neighborhood, Sant Narcís, a 'cluster' to ceramics, painting, design, fashion, and "qualsevol camp de les anomenades indústries creatives"21 (Sais, 2014, 23); a Gastronomic Week; a Film Festival; an annual Flowers Festival (Girona Temps de Flors); etc. Actually, Girona is proud to be known as the City of the Festivals (Ajuntament de Girona, 2016b).

\section{University of Girona and the Sci-Tech Park}

The role played by universities in the creative economy was studied by Florida et al. (2006). The authors stated that the participation of universities goes through their "ability to transfer research to industry, generate new inventions and patents, and spin-off its technology in the form of startup companies" (Florida, et al, 2006, 2). Starting with the 3T Florida's theory, which puts talent, technology, and tolerance at the very heart of the creative economy such a study advances an University-Creativity Index (UCI) that "combines a measure 
CREATIVE ECONOMY AT GIRONA, SPAIN:

A POTENTIAL, A HOPE, AND INVESTMENTS TO BE

of student concentration with the percent of a region's work force in the creative class." (32). At the conclusion, it mentions that:

Our findings suggest that the role of the university goes far beyond the "engine of innovation" perspective. Universities contribute much more than simply pumping out commercial technology or generating startup companies. In fact, we believe that the university's role in the first $\mathrm{T}$, technology, while important, has been overemphasized to date, and that experts and policymakers have somewhat neglected the university's even more powerful roles in the two other Ts - in generating, attracting and mobilizing talent and in establishing an tolerant social climate. (...) But university invention does not necessarily translate into regional high-tech industry and economic growth. (...) In order to be an effective contributor to regional creativity, innovation and economic growth, the university must be integrated into the region's broader creative ecosystem. On their own, there is only a limited amount that universities can do. In this sense, universities are necessary but insufficient conditions for regional innovation and growth. (Florida et al., 2006, 35)

On the other hand, the role played by science and technology parks (STP) on the creative economy has been also researched. For instance, UNESCO has promoted an international workshop fully dedicated to the theme on 2013 at Korea, whose keynote lecturer stated: "In the creative economy, the main player leading sustainable economic growth with job creation is science and technology parks (S\&T Parks) in technopolises, making direct contributions to fostering national and regional competitiveness" (Oh, 2013, 8). In the words of Weddle (2013), "(c)all it what you will - a science park, a research park, a technology park, or a technopole. (They offer) a variety of support services to knowledge-based companies and (make) significant contributions to regional economies". Notwithstanding, such a link between STP and the creative economy is not exempt of tensions or potential exclusion: 
CREATIVE ECONOMY AT GIRONA, SPAIN:

A POTENTIAL, A HOPE, AND INVESTMENTS TO BE

Creative industries enhance their potentialities for innovation, when they are embedded in networks of different enterprises, scientific institutions etc., which is often realized in Science and Technology Parks. (...) However, there are still shortcomings indicating a lack of economic expertise, for instance concerning the communication between creative industries executives and investors, the investment readiness, the deficient use of venture capital, and others, which are limiting the future potential of creative industries especially with regard to Science and Technology Parks. (...) However, in some German cities, like Munich, the positive role of Science and Technology Parks concerning their spatial and functional impact on the development of creative industries could be replaced by other factors, such as a vital urban structure within the inner city, characterized by a sound mixture of enterprises from different branches, which are spatially linked and therefore could benefit from networks, co-operation and mutual exchange. (Gruehn, 2014, 7-8)

The link between University of Girona (UdG) and the creative economy is generally done via its UNESCO Chair in Cultural Policies and Cooperation (www.catedraunesco.com) and its Campus Euromediterraneo de Turismo y Agua (e-MTA). For example, both the honorary director and the director of the UNESCO Chair have been involved with such theme in some extent: Mr. Alfons Martinell is faculty in the Master on Creative Economy at University Rey Juan Carlos (www.mastereconomiacreativa.es), while Mrs. Gemma Carbó has "creative economy and cultural diversity" as a topic of her course "Artistic Projects as Socio-educative Resources" (3101G05046/2016). The UdG's Institute for Research in Tourism, whose sixth line of research is "(c)reatividad, diversidad cultural y turismo", has creative industries as one of its targets (Universitat de Girona, 2016). Another (in)direct tie may be provided through the UdG's Science and Technology Park, ParcUdG.

With a name slightly different, the Scientific and Technological Park (www.parcudg.com) has as its objectives: the attraction, creation, and development of highly innovative companies; technology/knowledge based spinoffs or startups; R\&D intense entities to promote 
technologic transfer; innovation supportive structure; and the bridging and bonding promotion between such agents and the other 'glocal' players (ParcUdG, 2011, 5). As explained at the Catalonia's STP Association website, the UdG's Park "contributes to regenerating the business fabric through the creation of knowledge and technology based enterprises. In short, it is a park that combines support for the traditional economy with a commitment to the new economy." (XPCAT, 2016). Generally speaking, the UdG's STP has five specializations: food industry (e.g. meat), industrial technologies (e.g. machines, textiles, ceramics), biotechnology (medicine and food), TIC-Media (e.g. multimedia center, intelligent systems, tourism, cultural sector), and water (ParcUdG, 2011, 8).

\section{Creative economy + Girona}

The use of UdG's Library website to search for references that include simultaneously "creative economy" and Girona has returned no results whatsoever. Such search is not restricted to the Library's or UdG's database but is rather global. In theory, any existing book, report, paper, or else on the subject should appear here no matter whether publication location is inside or outside Spain. Per contra, a search for the Spanish translation ("economía creativa" + Girona) has conferred two single returns. Both references are related to a congress held at UdG, although they were associated to a more general topic indeed - one for CataIonia (Ganau, Paül, Rierapp, 2012), other for Madrid (Michelini, Méndez del Valle, 2012). The search for "creative industry" (single and plural) and Girona was equally fruitless, with zero references returned. The same repeated to the Spanish variations: "industria creativa" + Girona, "industrias creativas" + Girona. This absence does not mean that Girona (city/ province) has never appeared in the context of the creative economy/industry studies. This only indicates that none of those studies has either taken Girona as their main case object or used explicitly the concept of 'creative economy' and so perhaps employing different but analogue concepts / expressions. 
Despite the possibility to link both University of Girona and the creative economy ${ }^{22}$, a search over the thesis database at www.tdx.cat (Catalonia's internet-based database for thesis) brings no result whatsoever for UdG. It seems as, at least at a doctoral level, there has been an absence of such subject on research. This also happens when one searches into the whole database, meaning the expression "creative economy" seems to be also absent at the other provincial universities. However, when the search is done in Spanish ${ }^{23}$, looking for "economía creativa", three findings are presented. The first deal with the "Mediatic management of culture", from University of Múrcia (which is out of Catalonia). The second working with the 22@ Barcelona, a sci-tech hub at the provincial capital, from Polytechnic University of Catalonia; and the third, approaching the informational development at Buenos Aires, from the Open University of Catalonia. None of them were carried out at an Economics department or at any Business School, and both thesis were sustained at 2016. They were rather related to Education, Urbanism, and Sociology. Nonetheless, when one searches for "creative industry" instead, the database returns two references: the first, directly focused on the concentration of creatives industries in Europe (Serra, 2016), from Autonomic University of Barcelona; and the second, analyzing the influence of culture over employees' creativity (Torner, 2016), from Ramon Llull University. Now both were done at an Economic department or Business School, having been equally sustained at 2016 . Finally, the search for its Spanish version ("industria creativa") shows 6 results out of which only two are really new. The first is about the post media resistance for art and politics (Department of Design); and the second covers the Chinese Boxes (Department of Painting) - both from University of Barcelona.

\section{Critical analysis}

Some authors have introduced analysis that may help to understand the current delay of Girona over the creative economy. For example, a study of the Cambra de Comerç de Girona $(2010,35)$ argues that the companies at Girona have both a smaller dimension and an

\footnotetext{
22 Since the creative economy also includes the cultural sectors and is a wider concept, this paper has no longer searched for the "cultural economy" or "cultural industry". Actually, sometimes the cultural sectors are taken as a metonymy for the creative economy - which is inaccurate. 23 The translation for the Catalan language is identical to the Spanish version, with the same results.
} 
CREATIVE ECONOMY AT GIRONA, SPAIN:

A POTENTIAL, A HOPE, AND INVESTMENTS TO BE

average-or-lower technological intensity; that their resistance to innovation comes from a distrust in technology, a lack of better human capital, and an aversion to cooperation. Moreover, Girona is found to lie behind on critical prerequisites to more dynamic economies, such as the number of patents application/granted and technology pervasiveness. For instance:

The opposite characteristic excels in Girona, province in the autonomous region Catalonia. Catalonia reaches nearly the same level of patent efforts, which is more than the double of Spain's patent applications per millions of habitants. The difference to the Basque example is the technologically poorer region of Girona. The assumption of the outsourcing of research and development centers from Barcelona to the adjacent province of Girona seems to be illusive. With only 25.397 patent applications per million inhabitants Girona maneuvers on the same comparatively low level like Spain does. (...) Girona reaches with only 68 index points the third position. Even though the expenditure on R\&D is above Spanish national average for about $21 \%$, it is the only strong technological indicator in the Catalan city. The weak point is the patent applications. Especially in the high-tech, bio-tech and ICT sector, Girona is not competitive. Most of the patent applications are coming from the human necessities or the transporting sector. This fact in combination with the research and development spending can suggest a still existing agricultural characteristic. (Ulrich, 2012, 51,52,59).

El 5,0\% dels treballadors afiliats a la Seguretat Social (SS) a Girona el juny de 2015 ho estan sota uns epígrafs d'activitat que, segons les definicions exposades anteriorment, es poden considerar dins el grup de les indústries creatives. Aquest percentatge és relativament baix si es compara amb Barcelona, on el pes d'aquestes activitats representa l'11,6\%. Al conjunt de Catalunya inclouen el 7,9 \% dels afiliats(.) El percentatge de Girona també és dels més baixos en relació a algunes de les ciutats catalanes de més de 70.000 habitants(.) (Ajuntament de Girona, 2015a, 6) ${ }^{24}$ 
Also, the $\operatorname{OECD}(2010,57)$ shows how Girona, "with a more agricultural and lower-technology industries, (is) slightly below the Spanish average" regarding the productivity (GDP per worker in 2000 real prices). By their turn, Sellens, Chao, and Vilà (2013) have concluded that Girona lack of entrepreneurial capacity; has low educational and training stocks; lack of formal and collaborative innovation structures and practices; presents low ICT's uses; innovates weakly; lack of a strong local market (since the most competitive companies do export); has a competitive advantage very low due to costs; etc. Altogether, perhaps that explains why "the knowledge workers -as P. Drucker would call them- are more appeased to stay in Barcelona rather than living in Girona" (Ulrich, 2012, 27).

\section{Experience Economy}

Likewise the cultural industries, domains, sectors, and activities can be taken as components of the creative economy (Unesco, 2013, 22); the creative industries, domains, sectors, and activities may also be treated as elements of a larger concept - the experience economy. The experience economy is "closely [related] to the creative industries and culture by defining the core of the experience economy as industries that offer experiences as their primary products" (Bille, 2012, 96). Rigorously speaking, creativity ${ }^{25}$ is not a synonym nor a sinequa-non condition for an "experience". Actually, there have been critics to the use of such an umbrella concept (i.e. creativity and experience) whenever conjugated with economy, as in: creative economy or experience economy. In any case, this specific Scandinavian approach for the concept of 'experience economy', since it aggregates three streams in one, may be of interest to the case of Girona.

\footnotetext{
24 " $5.0 \%$ of workers affiliated to the Social Security (SS) at Girona (June 2015) are under some label of activity that, according to the definitions set out above, may be considered within the group of the creative industries. This percentage is relatively low if compared to Barcelona, where the weight of these activities represented $11.6 \%$. Catalonia as a whole includes $7.9 \%$ of such affiliates (.) The percentage of Girona is also one of the lowest in relation to some of the Catalan towns with more than 70,000 inhabitants" [free translation].

25 "la creativitat no és un atribut de cap "sector" econòmic en particular, però sí que es poden definir uns sectors bàsicament creatius que es defineixen com a indústries creatives." (Ajuntament de Girona, 2015a:3) "the creativity is not an attribute of any economic "sector" in particular, but you surely can define some sectors as basically creative that are defined as creative industries" [free translation]
} 
CREATIVE ECONOMY AT GIRONA, SPAIN:

A POTENTIAL, A HOPE, AND INVESTMENTS TO BE

Reading the Danish and Scandinavian books and reports published about the experience economy, it becomes clear that the Scandinavian use of the concept of experience economy seems to have derived from a mix of three different approaches and theories. Firstly, is Pine and Gilmore's book The Experience Economy (1999); secondly, the focus on creative industries in the United Kingdom with the first mappings of creative industries (DCMS 1998, 2001); and thirdly, Richard Florida's book The Rise of the Creative Class (2002). These three approaches together seem to represent the core of the experience economy wave that has spread in Denmark and several other countries, particularly in the Scandinavia. Each of the three approaches has something to do with experiences and creativity, but otherwise, they have little in common (Bille, 2012, 97).

Although Girona has been named a 'creative city', a 'knowledge platform', or a 'creative economy hub', the fact is that Girona remains still attached to a more traditional model of the economy despite thriving at services that are mainly intensive in managerial competence $^{26}$. If one bases itself over the KPMG's report, Girona seems to be better positioned at the management of activities that involve some level of knowledge / education / skills (e.g. health care and human capital supply), but not exactly at the core of the creativitybased wealth creation. Girona has been, then, a natural environment for managers ${ }^{27}-$ and, although already functioning as a cultural reference for Catalonians, it needs more investments to become a competitive incubator for the creative class (whose activities are most akin to the trinomial 'Silicon Valley', 'Hollywood', and 'Ministry of Culture' - to put it simple). It is positive to recognize the local / regional vocation so to invest more appropriately the public funds, avoiding pitfalls and low-returns when dedicated to policy making / implementation.

\footnotetext{
26 The majority of the companies are small or medium, and family owned and managed: "at Girona's counties $82 \%$ of the companies are familiar" (El Gerió, 2015, free translation), or 80,9 \% (Guinjoan, Murillo, Pons; 2004, 22). 
CREATIVE ECONOMY AT GIRONA, SPAIN:

A POTENTIAL, A HOPE, AND INVESTMENTS TO BE

Bille and Lorenzen (2008) have reached a tentative demarcation of the experience economy by defining three groups of experience industries by differentiating between creativity at the production side and experiences on the consumption side: (1) Creative experience industries (industries that have experience as the primary goal and where artistic creativity is essential to its production). For example, theater, music, visual arts, literature, film, computer games, etc. (2) Experience industries (industries that have experience as the primary goal, but where artistic creativity is not essential). For example, museums, libraries, cultural heritage sites, natural and green areas, restaurants, the pornography industry, spectator sports, etc. (3) Creative industries (industries where artistic creativity is essential but which do not have experience as a primary goal: they are not intended directly for the consumer market but instead provide services to business (B2B) which are built into or around mixed products). For example, design, architecture, advertising, etc. (Bille, 2012, 100)

Such Scandinavian approach is relevant because it "links the experience economy closely with cultural activities, and to the expectation of economic return and economic development" (93). Pivoted in its managerial competitive advantage ${ }^{28}$, Girona may attract both Barcelona's creative class, businesses, and companies; marketing itself as a good place to live, to raise children, to have companies hosted and managed (although the real market remaining in Barcelona), but mostly the perfect environment to have 'experiences' - personal, familiar, and corporate. Therefore, Girona recognizes that Barcelona is hors concours

\footnotetext{
28 "La familia gironina es, y ha sido tradicionalmente, no sólo una unidad familiar (social), sino también, una unidad económica. Y por tanto, sus miembros tienen una clara y temprana formación y actividad administrativa y económica. Esto es debido a que: 1. La economía familiar ha sido clave en el desarrollo económico en Cataluña y Girona. 2. El turismo ha sido clave en desarrollo de España, Cataluña y Girona. Múltiples familias son, a su vez, pequeñas empresas hoteleras, restaurantes, bares. 3. La industria agroalimentaria es igualmente clave. Una parte importante de las familias tienen pequeñas explotaciones de producción agroalimentaria catalana. La idea es que, este contexto, evidencia la existencia de una gran tradición de las familias gironinas como unidades económicas encargadas de la administración y producción de bienes y servicios. Esto comporta que los integrantes de las familias gironinas han desarrollado capacidades y habilidades, que los hacen claramente competitivos a la hora de asumir la gestión de la economía creativa." (J. G. E. Marulanda, personal communication, March 28th, 2017) "The gironin family is, and has traditionally been, not only a familial (social) unit, but also an economic unit. Therefore, its members have a clear and early formation on the administrative and economic activity. This is because: 1 . Familial economy has been key to the economic development in Catalonia and Girona. 2. Tourism has been key to the development of Spain, Catalonia and Girona. Multiple families are small companies such as hotels, restaurants, bars. 3. The agro-food industry is equally key. An important part of the families have small farms linked to the Catalan agro-food production. In this context, it shows the existence of a great tradition of the gironin families as economic units in charge of the administration and production of goods and services. This means that the members of the gironin families have developed abilities and skills that make them clearly competitive when it comes to managing the creative economy." [free translation]
} 
CREATIVE ECONOMY AT GIRONA, SPAIN:

A POTENTIAL, A HOPE, AND INVESTMENTS TO BE

as a milieu to creative economy generation, and starts presenting itself also as an appealing support to the experience economy management. Such perspective is integrative (not excluding), putting Girona at the center of the creative economy: not exclusively to generate it, but to manage it as well.

\begin{tabular}{|c|c|c|}
\hline & Level of analysis & $\begin{array}{l}\text { Primarily relevant to areas } \\
\text { such as: }\end{array}$ \\
\hline $\begin{array}{l}\text { Focused value creation in the } \\
\text { experience areas } \\
\text { "The DCMS tradition" }\end{array}$ & Industries & $\begin{array}{l}\text { Primarily commercial } \\
\text { experience areas: } \\
\text { - Photography } \\
\text { - Computer games } \\
\text { - Printed media } \\
\text { - Music industry } \\
\text { - Amusement parks etc. } \\
\text { - Restaurants etc. } \\
\text { - Dorno industry } \\
\text { - Architecture } \\
\text { - Fashion } \\
\text { - Advertising }\end{array}$ \\
\hline $\begin{array}{l}\text { Broad value creation in } \\
\text { association with experience } \\
\text { areas } \\
\text { "Pine and Gilmore tradition" }\end{array}$ & $\begin{array}{l}\text { The individual company or } \\
\text { the individual products or } \\
\text { services }\end{array}$ & $\begin{array}{l}\text { Mixed products. } \\
\text { Primarily B2B areas, like: } \\
\text { - Design } \\
\text { - Advertising }\end{array}$ \\
\hline $\begin{array}{l}\text { Experiences as urban and } \\
\text { regional development } \\
\text { "Richard Florida and the } \\
\text { creative class" }\end{array}$ & Geographical area & $\begin{array}{l}\text { Location specific experiences } \\
\text { as: } \\
\text { - Theatres } \\
\text { - Concerts } \\
\text { - Events and festivals } \\
\text { - Museums } \\
\text { - Heritage sites } \\
\text { - satural and green } \\
\text { - Spectator sports }\end{array}$ \\
\hline
\end{tabular}

Figura 5. Three ways to create market value in the experience economy (Bille, 2012, 103)

Reverte et al., (2016) have applied the Richard Florida's theory to touristic cities from the Spanish Mediterranean system (see the following Figure. 5. 'Indicadores de creatividad'), where Girona is implied as a provincial capital. However, Girona was never named - neither as city or as province. But such indicators do form part of the experience economy. A list with several other indicators that could contribute to analyze the experience economy at Catalonia's cities is present by AQR-IREA (2007, 6-9). 
CREATIVE ECONOMY AT GIRONA, SPAIN:

A POTENTIAL, A HOPE, AND INVESTMENTS TO BE

Fig. 1. Indicadores de creatividad

\begin{tabular}{|c|c|c|c|c|c|c|}
\hline Tipo & $\begin{array}{c}\text { ID. } \\
\text { Indicad. }\end{array}$ & Indicador & Antecedentes & $\begin{array}{l}\text { Descripción proxy } \\
\text { seleccionado }\end{array}$ & Fuente & Criterio \\
\hline \multirow[t]{6}{*}{ Tolerancia } & T0.1 & Homosexualidad & $\begin{array}{l}\text { US_Florida (2004), Dublin_Murphy y Redmon } \\
\text { (2009), Sweden_Ström y Nelson (2010), } \\
\text { Spain_Pesquera et al. (2010) }\end{array}$ & $\begin{array}{l}\text { Población con pareja } \\
\text { del mismo sexo / } \\
\text { total población }\end{array}$ & $\begin{array}{l}\text { Censo INE } \\
2011\end{array}$ & $\begin{array}{l}\text { Más } \\
\text { mejor }\end{array}$ \\
\hline & TO.2 & $\begin{array}{l}\text { Diversidad } \\
\text { cultural }\end{array}$ & $\begin{array}{l}\text { US_Florida (2004), Dublin_Murphy y Redmon } \\
\text { (2009), Sweden_Ström y Nelson (2010), } \\
\text { Spain_Pesquera et al. (2010), Sweden y } \\
\text { UK_Clifton et al (2012), The Nordics_Andersen et } \\
\text { al (2010), }\end{array}$ & $\begin{array}{l}\text { Población nacida en } \\
\text { el extranjero / total } \\
\text { población }\end{array}$ & $\begin{array}{l}\text { Censo INE } \\
2011\end{array}$ & $\begin{array}{l}\text { Más } \\
\text { mejor }\end{array}$ \\
\hline & TO. 3 & $\begin{array}{l}\text { Actividades } \\
\text { artisticas }\end{array}$ & $\begin{array}{l}\text { US_Florida (2004), Sweden_Ström y Nelson } \\
\text { (2010), Spain_Pesquera et al. (2010), Sweden y } \\
\text { UK_Clifton et al (2012), The Nordics_Andersen et } \\
\text { al (2010) }\end{array}$ & $\begin{array}{l}\text { Artistas, escritores y } \\
\text { profesiones similares } \\
\text { / población activa }\end{array}$ & $\begin{array}{l}\text { Censo INE } \\
2011\end{array}$ & $\begin{array}{l}\text { Más } \\
\text { mejor }\end{array}$ \\
\hline & TO.4 & $\begin{array}{l}\text { Diversidad de } \\
\text { género en el } \\
\text { empleo }\end{array}$ & & $\begin{array}{l}\text { Ratio de } \\
\text { hombres/mujeres } \\
\text { que ocupan cargos de } \\
\text { dirección o gerencia }\end{array}$ & $\begin{array}{l}\text { Censo INE } \\
2011\end{array}$ & $\begin{array}{l}\text { Menos } \\
\text { mejor }\end{array}$ \\
\hline & TO.5. & $\begin{array}{l}\text { Parejas de } \\
\text { hecho }\end{array}$ & & $\begin{array}{l}\text { Población que vive } \\
\text { con pareja de hecho / } \\
\text { total población }\end{array}$ & $\begin{array}{l}\text { Censo INE } \\
2011\end{array}$ & $\begin{array}{l}\text { Más } \\
\text { mejor }\end{array}$ \\
\hline & T0.6 & $\begin{array}{l}\text { Hogares } \\
\text { monoparentales }\end{array}$ & & $\begin{array}{l}\text { Población que vive en } \\
\text { hogares } \\
\text { monoparentales / } \\
\text { total población }\end{array}$ & $\begin{array}{l}\text { Censo INE } \\
2011\end{array}$ & $\begin{array}{l}\text { Más } \\
\text { mejor }\end{array}$ \\
\hline \multirow[t]{4}{*}{ Tecnología } & TE.1. & $\begin{array}{l}\text { Innovación en } \\
\text { patentes }\end{array}$ & $\begin{array}{l}\text { US_Florida (2004), UE_Florida y Tinagli (2004), } \\
\text { China_Li y Florida (2006), Sweden_Stróm y } \\
\text { Nelson (2010), Spain_Pesquera et al. (2010) }\end{array}$ & $\begin{array}{l}\text { Patentes concedidas } \\
\text { / total población }\end{array}$ & $\begin{array}{l}\text { OEPM } \\
2011\end{array}$ & $\begin{array}{l}\text { Más } \\
\text { mejor }\end{array}$ \\
\hline & TE. 2 . & $\begin{array}{l}\text { Innovación en } \\
\text { modelos de } \\
\text { utilidad }\end{array}$ & & $\begin{array}{l}\text { Modelos de utilidad } \\
\text { concedidos / total } \\
\text { población }\end{array}$ & $\begin{array}{l}\text { OEPM } \\
2011\end{array}$ & $\begin{array}{l}\text { Más } \\
\text { mejor }\end{array}$ \\
\hline & TE. 3 . & Tecnologia & $\begin{array}{l}\text { Sweden y UK_Clifton et al (2012), Sweden_Strōm } \\
\text { y Nelson (2010); The Nordics_Andersen et al } \\
\text { (2010); US_Florida (2004) }\end{array}$ & $\begin{array}{l}\text { Población en } \\
\text { actividades de alta y } \\
\text { media-alta tecnología } \\
\text { (no incluye l+D)/ } \\
\text { población activa }\end{array}$ & $\begin{array}{l}\text { Censo INE } \\
2011\end{array}$ & $\begin{array}{l}\text { Más } \\
\text { mejor }\end{array}$ \\
\hline & TE.4. & $1+D$ & $\begin{array}{l}\text { UE_Florida y Tinagli (2004), Spain_Pesquera et } \\
\text { at. (2010), The Nordics_Andersen et al (2010) }\end{array}$ & $\begin{array}{l}\text { Población en } \\
\text { actividades de I+D/ } \\
\text { población activa }\end{array}$ & $\begin{array}{l}\text { Censo INE } \\
2011\end{array}$ & $\begin{array}{l}\text { Más } \\
\text { mejor }\end{array}$ \\
\hline \multirow[t]{6}{*}{ Talento } & TA.1. & $\begin{array}{l}\text { Capital humano } \\
\text { (titulados } \\
\text { universitarios) }\end{array}$ & $\begin{array}{l}\text { US_Florida (2004), UE_Florida y Tinagli (2004), } \\
\text { Sweden_Strōm y Nelson (2010), Spain_Pesquera } \\
\text { et al. (2010), Sweden yUK_Clifton et al (2012). } \\
\text { The Nordics_Andersen et al (2010) }\end{array}$ & $\begin{array}{l}\text { Población con } \\
\text { estudios } \\
\text { universitarios / total } \\
\text { población }\end{array}$ & $\begin{array}{l}\text { Censo INE } \\
2011\end{array}$ & $\begin{array}{l}\text { Más } \\
\text { mejor }\end{array}$ \\
\hline & TA.2. & Doctores & & $\begin{array}{l}\text { Población con } \\
\text { estudios de } \\
\text { doctorado finalizados } \\
\text { / población }\end{array}$ & $\begin{array}{l}\text { Censo INE } \\
2011\end{array}$ & $\begin{array}{l}\text { Más } \\
\text { mejor }\end{array}$ \\
\hline & TA.3. & $\begin{array}{l}\text { Atracción de } \\
\text { capital humano }\end{array}$ & & $\begin{array}{l}\text { Porcentaje de } \\
\text { población extranjera } \\
\text { llegada en los últimos } \\
5 \text { an̂os con estudios } \\
\text { superiores / total } \\
\text { extranjeros }\end{array}$ & $\begin{array}{l}\text { Censo INE } \\
2011\end{array}$ & $\begin{array}{l}\text { Más } \\
\text { mejor }\end{array}$ \\
\hline & TA.4. & Emprendeduria & & $\begin{array}{l}\text { Emprendedores } \\
\text { (empresarios y } \\
\text { profesionales que } \\
\text { emplean personal)/ } \\
\text { Población activa } \\
\end{array}$ & $\begin{array}{l}\text { Censo INE } \\
2011\end{array}$ & $\begin{array}{l}\text { Más } \\
\text { mejor }\end{array}$ \\
\hline & TA.5. & Clase creativa & $\begin{array}{l}\text { UE_Florida y Tinagli (2004), Spain_Pesquera et } \\
\text { al. (2010), Sweden y UK_Clifton et al (2012), The } \\
\text { Nordics_Andersen et ol (2010) }\end{array}$ & $\begin{array}{l}\text { Población en } \\
\text { actividades de clase } \\
\text { creativa (CNAE)/ } \\
\text { población activa } \\
\end{array}$ & $\begin{array}{l}\text { Censo INE } \\
2011\end{array}$ & $\begin{array}{l}\text { Más } \\
\text { mejor }\end{array}$ \\
\hline & TA. 6 . & $\begin{array}{l}\text { Atracción de clase } \\
\text { creativa }\end{array}$ & & $\begin{array}{l}\text { Extranjeros creativos } \\
\text { llegados a España en } \\
\text { los últimos } 5 \\
\text { años/extranjeros }\end{array}$ & $\begin{array}{l}\text { Censo INE } \\
2011\end{array}$ & $\begin{array}{l}\text { Más } \\
\text { mejor }\end{array}$ \\
\hline Creatividad & & $\begin{array}{l}\text { Índice global de } \\
\text { creatividad }\end{array}$ & & $\begin{array}{l}\text { Combinación de los } \\
\text { indices de tolerancia, } \\
\text { tecnologia y talento }\end{array}$ & & $\begin{array}{l}\text { Más } \\
\text { mejor }\end{array}$ \\
\hline
\end{tabular}

Elaboración propia.

Figura 5. Indicadores de creatividad (Reverté et al., 2016, 11-12) 


\section{Conclusiones}

Although creative sectors and industries exist in Girona, the academic and technical quantification / qualification of the phenomena are still to be done. Therefore, it is also necessary to invest in research and studies that approach the "creative economy of Girona" - a mandatory step to subsidize the public policy plans and actions. In such ground (relative absence of knowledge production in the field) Girona is with the majority, since the attention is usually directed to the main cities such as London, Paris, New York, and Barcelona. Then, such absence is a transient condition rather than a structural problem, and can be faced and fixed.

The finding that Girona is specialized in services intensive in managerial competences may be conducive to a broader strategy. Instead of only investing into a more creative economy generation, also presenting itself as a potential partner for all the existing players at the experience economy (with special focus on Barcelona) - a wider concept through the Scandinavian point of view. In sum, Girona has vocation to become a management contractor servicing the cultural sectors, creative industries, creative class, and the whole experience economy even if the market may view them as being primarily located at Barcelona.

As soon as the policy-makers realize that Girona does have a competitive advantage in management, they can continue to pursuit the vein of the 'creative economy', 'knowledge economy', 'new economy' - doing so centered on how to better manage such social project. For example, offering the city/province as a high-quality environment to live; close to the major hub for the creative economy (Province of Barcelona), but away enough to present lower levels of prices, traffic, pollution, violence, stress, etc.; emphasizing the benefits of raising family's children in a smaller city; the proximity of mountain and beaches, plenty of bucolic places to visit in daily escapades; etc. Thus, Girona could attract part of the creative class that work in Barcelona, not necessarily to relocate their businesses, but rather as to have them living here with their families - note that telework does part of the creative economy. Such managerial way to envisage Girona is realistic, given the local/regional competences and placement. 
The ParcUdG could act accordingly to such vision as offering working stations so the executives/employees could work for their Barcelona's companies without commuting every day; opening for any person to use its premises to do business related to the experience economy, including the possibility to formalize such businesses through the Parc's legal entity (paying local taxes); developing a hosting system for remote-located $\mathrm{CCl}$ firms (e.g. a Barcelona's technology company that exists formally in, and effectively is run at Girona); receiving the University of Girona's students so they can be entrepreneurs also through the Parc's legal entity; creating an observatory for 'value generation' at the ParcUdG (in a more detailed way than APTE $(2010,7)$ did for Catalonia); cooperating with the cultural industry entities (such as Bòlit) as their managerial partner, in order to maximize their market potential; functioning as the local/regional observatory for the $\mathrm{CCl}$; and so forth. Such managerial turning could also be an option to fight back the financial crisis in which the ParcUdG currently finds itself on (EuropaPress, 2016). 


\section{References}

Agencia INCAT (2014). Podríamos decir que la cocina catalana es hoy el Silicon Valley de la cocina mundial. Retrieved from: http://tinyurl.com/z4fpen4 Access: 26/12/2016

Ajuntament de Barcelona. (2015). Barcelona em xifres 2015. Principals indicadors econòmics de l'àrea de Barcelona. http://tinyurl.com/jfl85et Retrieved from: Access: 12/03/2017

Ajuntament de Girona. (2016). Activitats econòmiques, per tipus. L'Observatori. Retrieved from: http://tinyurl. com/grllhdk Access: 28/12/2016.

Ajuntament de Girona. (2016a). L'Ajuntament de Girona aposta per la indústria cultural $i$ creativa com a motor econòmic de future. Retrieved from: http://tinyurl. com/ht37kz9.

Ajuntament de Girona. (2016b). Girona Ciutat de Festivals. Retrieved from: http://tinyurl.com/zzeuf44 Access: 29/12/2016

Ajuntament de Girona. (2015). Girona, Destinació de Turisme Esportiu. Retrieved from: http://tinyurl.com/ zfpnkms

Ajuntament de Girona. (2015a). Indústries culturals i creatives a Girona. Àrea de Promoció i Ocupació, Observatori de l'Economia i l'Ocupació.

Ajuntament de Girona. (2014). El turisme creatiu i industrial, a debat a 'A Girona Emprèn parlem de...'. Retrieved from: http://tinyurl.com/gqco3z4

Ajuntament de Girona. (2014a). Girona International Mapping Festival. Retrieved from: http://tinyurl.com/ zhrmaer.

Ajuntament de Girona. (2011). Superar la crisi, la nostra priorotat. Pla de Govern 2011-2015. v: http://tinyurl. $\mathrm{com} / \mathrm{h} 3 \mathrm{qf6} 6 \mathrm{w}$

Aldia. (2016). Puigdemont veu potencial TIC a Catalunya per competir i col-laborar amb Silicon Valley. Retrieved from: http://tinyurl.com/hqdvurn
APTE. (2010). Principales estadísticas de las actividades de los Parques Científicos y Tecnológicos en 2010. Campanillas, Málaga (Spain).

AQR-IREA. (2007). Sistema d'indicadors estratègics de seguiment municipal: memòria final. Grup de Recerca AQR, Institut de Recerca em Economia Aplicada (IREA), Universitat de Barcelona.

Area Metropolitana de Barcelona. (2011). Per Afrontar la Crisi: la metropoli de Barcelona. Anuari Metropolita de Barcelona, IERMB.

Azqueta, C. (2014). Les empreses culturals en clau creativa. In: DeCultura 11, Desembre.

Barcelona Treball. (2013). Indústries Culturals. Informe Sectorial 2013. Amb la collaboració de: Associació Professional de la Gestió Cultural de Catalunya.

Bille, T. (2012). The Scandinavian approach to the experience economy - does it make sense? International Journal of Cultural Policy 18(1), 93-110.

Retrieved from: https://tinyurl.com/ybtswokv

Bòlit Emprèn. (2013). Accions de suport a les arts visuals i a les indústries creatives de Girona i comarques. Memòria digital del projecte. Retrieved from: tinyurl.com/haspgu9

Cambra de Comerç de Girona. (2010). Girona 2010. Les comarques gironines davant el repte de la nova economia global. Girona, 2010.

Cambra de Comerç de Girona. (2011). Cent anys d'economia a les Comarques Gironines, Girona, 447.

Creative Tourism Girona. (2016). Què Fem. Retrieved from: http://tinyurl.com/zy6jmcp

Diari de Girona. (2013). Sunyer explica com convertir Girona en el 'Silicon Valley de les arts' sense costos. Retrieved from: http://tinyurl.com/jaj9gmo

Diari de Girona. (2011). Bosch vol convertir Girona en el Silicon Valley de Catalunya. Retrieved from: tinyurl.com/gmt9wrw 
Diputació de Girona. (2016). La Diputació presenta cinc PECT a la convocatòria dels FEDER de la Generalitat. Retrieved from: http://tinyurl.com/hbyr7zm Access: 27/12/2016.

El Gerió, (2015). La meitat de les empreses familiars gironines no planifiquen el seu relleu generacional. Retrieved from: http://tinyurl.com/j4uwu6m

EuropaPress. (2016). El Parc Científic i Tecnològic de la UdG pide un mes para renegociar su deuda. Retrieved from: http://tinyurl.com/gv84qku.

EY. (2014). Creating growth. Measuring cultural and creative markets in the EU. Retrieved from: http://tinyurl.com/j36hscz

Florida, R.; Gates, G.; Knudsen, B; Stolarick, K. (2006). The university and the creative economy. Fairfax / Pittsburgh / Los Angeles: George Mason University / Carnegie Mellon / UCLA.

Ganau, J.; Paül, D.; Rierapp, P. (2012). La distribución de la economía creativa y del conocimiento en catalunya. Dinámicas en los espacios metropolitanos y no metropolitanos. In: Crisis económica e impactos territoriales - V Jornadas de Geografía Económica AGE, Univ. de Girona 2012. Retrieved from: https:// tinyurl.com/y7ku9cgh

Gausa, M. (2010). Catalunya: hiperterritoris / multiciutats /geourbanitats: nous models en xarxa. In: Fundació CatDem. La Catalunya en Xarxa. Catarroja: Editorial Afers.

Generalitat de Catalunya. (2014). La DGCEC y los sectores culturales en Cataluña. Dirección general de creación y empresas culturales, Instituto Catalán de las Empresas Culturales.

Generalitat de Catalunya. (2013). RIS3CAT - Anàlisi dels àmbits sectorials liders I de les capacitats en technologies facilitadores transversals. Barcelona.

Girona Emprèn. (2014). Girona, municipi cooperatiu. Sessió d'experiència de projectes culturals i creatius. Girona.
Gruehn, D. (2014). Creative industries in germany recent development and the role of science and technology parks. World Technopolis Review 3(1), 30-38.

Guinjoan, M.; Murillo, C.; Pons, J. (2004). L'empresa familiar a Catalunya - Quantificació i característiques. Generalitat de Catalunya / CIDEM.

IDESCAT. (2016). Macromagnituds i impostos. Retrieved from: http://tinyurl.com/gwg3gwk

IERMB. (2012). Per afrontar la crisi: la metropoli de Barcelona. Anuari metropolita de Barcelona, Area Metropolitana de Barcelona, Bellaterra, Spain, 359.

KPMG. (2016). Girona 100, SA - Anàlisi del comptes de 2014 i projecció macroeconòmicai empresarial 2016. Girona, Spain. Retrieved from: https://tinyurl.com/ y8bzqdzh

Méndez, R.; Michelini, J. J.; Prada, J.; Tébar, J. (2012). Economía creativa y desarrollo urbano en España: una aproximación a sus lógicas espaciales.

Eure 38(113), 5-32.

Michelini, J. J.; Méndez del Valle, R. (2012). Economía y estrategias de promoción en la región metropolitana de Madrid. In: Crisis económica e impactos territoriales - V Jornadas de Geografía Económica AGE, Univ. de Girona 2012.

OECD. (2010). Reviews of regional innovation: Catalonia, Spain. Retrieved from: tinyurl.com/jujxntf

Oh, D-S. (2013). R\&BD 3.0: science and technology parks in the creative economy. In: UNESCO-WTA International Training Workshop. Daejeon, Korea, September 24-27th.

Panal, G. G.; Yáñez, C. N. (2012). Industrias culturales en ciudades españolas. Un primer acercamiento. Revista de Estudios Regionales 94, 71-103.

ParcUdG. (2011) La contribución del Parc Científic i Tecnològic de la Universitat de Girona al Libro Verde. Retrieved from: http://tinyurl.com/j8bm66v 
Perfil de la Ciutat. (2016). Girona. Retrieved from: https://tinyurl.com/y8jrzsvchttp://tinyurl.com/h5gy5kn

Puig, O. (2012). Cap a una economia de serveis. Revista de Girona 274, 48-52.

Reverté, F. G. et allí. (2016). La localización de la clase creativa en ciudades turísticas. Un análisis a escala local del sistema urbano Mediterráneo español. Investigaciones Turísticas 11, 1-29. Retrieved from: https://tinyurl.com/y8z8klpb

Sais, C. (2014) Sant Narcís, el barri artístic. Girona Cultura 5. Retrieved from: http://tinyurl.com/hgm86yy

Sellens, J. T.; Chao, A. D.; Vilà, M. P. C. (2013). L'Empresa gironina a l'economia del coneixement: noves fonts de productivitat i competitivitat? Observatori de Tecnologies de la Informació i la Comunicació de Girona (OTIC), Universitat de Girona.

Serra, D. S. (2016). Determinants of the concentration of creative industries in Europe: a comparison between Spain, Italy, France, United Kingdom and Portugal. PhD thesis, Universitat Autònoma de Barcelona.

The Guardian. (2015). Why Girona makes the perfect base for cyclist Dan Craven. Retrieved from: http://tinyurl.com/hqkk7nm Access: 29/12/2016.

Torner, F. M. (2016). Employee creativity and culture. Evidence from an examination of culture's influence on perceived employee's creativity in Spanish organizations. PhD thesis, Universitat Ramon Llull.

Triay, S. E. (2010). De fàbrica d'Espanya a motor d'Europa: la Catalunya creativa. In: Fundació CatDem. La Catalunya en Xarxa. Catarroja: Editorial Afers.

Ulrich, P. (2012). Economic development and crosslinking of knowledge in the Pyrenees: a case study on structural change in a "technological triangle" based on the creativity theory by Richard Florida. Master Thesis, University of Frankfurt.
Unesco. (2013). Creative economy report - widening local development pathways. Special Edition. Retrieved from: http://tinyurl.com/ljufl28

Universitat de Girona. (2016). Campus Euromediterraneo de Turismo y Agua. Instituto de Investigación en Turismo. Retrieved from: http://tinyurl.com/hsauhr6

Vilà, P. C.; Pagès, J. L. (2008) Science and technology parks: creating new environments favourable to innovation. Paradigmes 0, May, 141-149.

Weddle, R. (2013). All inclusive: how areas of innovation are challenging and changing the model for research and science parks. Site Selection Magazine, July.

XPCAT. (2016). Parc Científic i Tecnològic de la Universitat de Girona. Retrieved from: http://tinyurl.com/gw72lk5 